\title{
HERBAGE PRODUCTION FROM OVERDRILLED PASTURE IN CANTERBURY
}

\author{
E. W. VARTHA \\ Grasslands Division, DSIR, Lincoln Regional Station, P.B., \\ Christchurch
}

\begin{abstract}
A bstract
Established Ruanui ryegrass pasture on Ruapuna and Lismore soils in Canterbury was overdrilled with Ariki or Tama ryegrasses. Other treatments investigated were paraquat spray before overdrilling and application of nitrogen after overdrilling. The Lismore soil was flood irrigated in spring and autumn, but not in summer.

Paraquat spray enabled superior establishment of Tama ryegrass. Total annual herbage yields were 4400 to $5100 \mathrm{~kg} / \mathrm{ha}$ on the Ruapuna soil and 8900 to $11100 \mathrm{~kg} / \mathrm{ha}$ on the Lismore soil. Applied nitrogen $(112 \mathrm{~kg} / \mathrm{ha})$ increased grass yield in cool season by 7 to $10 \mathrm{~kg}$ DM per kg N. Maximum yields were 2590 and $3200 \mathrm{~kg} / \mathrm{ha}$ on Ruapuna and Lismore soils, respectively. Because of competition between Tams ryegrass and existing pasture components, there was a marked slump in herbage production when Tama ryegrass died in spring.

Repeat overdrilling of paraquat-treated pasture the following autumn with Tama ryegrass gave total annual herbage yields of $5800 \mathrm{~kg} / \mathrm{ha}$ on the Ruapuna soil and $11800 \mathrm{~kg} / \mathrm{ha}$ on the Lismore soil. Applied nitrogen increased grass yield in cool season by 11 to $17 \mathrm{~kg}$ DM per $\mathrm{kg} \mathrm{N}$. Maximum yields were 2370 and $4820 \mathrm{~kg} / \mathrm{ha}$ on Ruapuna and Lismore soils, respectively.

Pasture overdrilled with Ariki ryegrass was measured in the second year only. Total annual herbage yields were 5700 to 6300 $\mathrm{kg} / \mathrm{ha}$ on the Ruapuna soil and 11300 to $11800 \mathrm{~kg} / \mathrm{ha}$ on the Lismore soil. Applied nitrogen increased grass yield in cool season by 8 to $15 \mathrm{~kg} \mathrm{DM}$ per $\mathrm{kg} \mathrm{N}$. Maximum yields were 1860 and 4180 $\mathrm{kg} / \mathrm{ha}$ on Ruapuna and Lismore soils, respectively.

Pasture overdrilled with Tama ryegrass grew a greater proportion of its cool season grass yield in winter than in autumn whilst the reverse result was shown for pasture overdrilled with Ariki ryegrass. Mixture of the two species is suggested for overdrilling, to provide for improved cool season herbage yield.
\end{abstract}

\section{INTRODUCTION}

'PÁstURE PRODUCtion in Canterbury is characterized by a low contribution of winter growth to annual herbage yield, requiring cultivation for the growing of supplementary crops. However, with the development of overdrilling" techniques, cool

\footnotetext{
*Sowing species into existing swards, seed and fertilizer being placed separately and covered with soil in cultivated grooves, in a single operation with specially designed machinery.
} 
season active grasses may be sown into existing pasture. The advantages of these species may not be realized in winter if low temperatures affect availability of nitrogen from the soil. Thus, a role for nitrogen fertilizer may be established.

In the present experiments, cool season active ryegrasses, either 'Grasslands Tama' or 'Grasslands Ariki', were overdrilled into existing Ruanui ryegrass pastures and nitrogen fertilizer was applied to determine what levels of cool season herbage yield could be obtained.

\section{EXPERIMENTAL}

Sites were in the View Hill district of Oxford (Ruapuna soil) and in the Lismore district of Ashburton (Lismore soil). These soils are described in Scil Bureau Bulletin 14 (Kear et al., 1967). The pastures had been established for at least five years and on the Lismore soil had been flood-irrigated.

Three blocks of pasture were half overdrilled with Ariki ryegrass and half with Tama ryegrass. Cross treatments were a factorial design of with and without spray treatment before overdrilling, by, with and without nitrogenous fertilizer applied after overdrilling. These four treatments were separately fenced for grazing; within each, the overdrilled grasses were grazed in common. Plot size was $12 \mathrm{~m}$ by. $12 \mathrm{~m}$.

The experiments commenced in February 1970. Pasture was close-grazed by sheep and, at the Ashburton site, then irrigated. The appropriate plots were sprayed with $280 \mathrm{~g}$ active ingredient per hectare of paraquat and all plots immediately overdrilled. Seeding rate was $16.8 \mathrm{~kg} / \mathrm{ha}$ for Ariki ryegrass and $33.6 \mathrm{~kg} / \mathrm{ha}$ for Tama ryegrass with $188 \mathrm{~kg} / \mathrm{ha}$ of superphosphate drilled with the seed. At the commencement of 'autumn, winter, spring and summer, $56 \mathrm{~kg} \mathrm{~N} / \mathrm{ha}$ (as lime-ammonium nitrate) was applied to the appropriate plots.

At the Oxford site there were four grazings per year, commencing in August, while at the Ashburton site there were five grazings per year, commencing in June. Sufficient sheep were used to fully utilize the herbage in 48 hours. The Ashburton site was irrigated in spring and before overdrilling in autumn only, as the co-operating farmer was unable to supply water in summer.

Herbage yields were obtained prior to each grazing by harvesting to $25 \mathrm{~mm}$, four $0.25 \mathrm{~m}^{2}$ quadrats per plot.

The Tama ryegrass strips only were redrilled in the following autumn. No further paraquat spray was applied before this over- 
drilling. A further $188 \mathrm{~kg} / \mathrm{ha}$ of superphosphate was drilled with the Tama seed and also was topdressed on the Ariki strips.

\section{RESULTS AND DISCUSSION}

Meteorological data in Table 1 indicate the general pattern of rainfall on the Canterbury Plains from foothills to mid-coast. Rainfall for both the sites would be about that recorded at Darfield but as the Oxford site was near the outer gorge of the Waimakariri River the adverse effects of the drying north-west wind were more severe than at Ashburton. Mean monthly temperatures in winter in Canterbury are about 4 " C.

TABLE 1: RAINFALL DATA (mm) FROM OFFICIAL METEOR. OLOGICAL STATIONS IN CANTERBURY

\begin{tabular}{|c|c|c|c|c|c|}
\hline & & & Highbank & Darfield & Ashburton \\
\hline Altitude ( $\mathrm{n}$ & & & 340 & 200 & 100 \\
\hline \multicolumn{6}{|c|}{ Cool season (Mar.-Aug.) : } \\
\hline 1970-1 & - -5 & $\ldots$. & 430 & 370 & 390 \\
\hline 1971-2 & $\ldots$ & $\ldots$ & 370 & 300 & 310 \\
\hline \multicolumn{6}{|c|}{ Warm season (Sep.-Feb.) : } \\
\hline 1970-1 & $\ldots \quad \ldots$ & . & 400 & 310 & 260 \\
\hline 1971-2 & $\ldots$ & $\ldots$ & 430 & 320 & 270 \\
\hline \multicolumn{6}{|l|}{ Total: } \\
\hline 1970-1 & ... & $\ldots$ & 830 & 680 & 650 \\
\hline $1971-2$ & $\ldots$ & & 800 & 620 & 580 \\
\hline
\end{tabular}

YIELD FOR 1970-1 FROM PASTURE OVERDRILIED with TAMA Ryegrass In Autum 1970 TABLE 2

The pasture at Oxford contained more unsown grasses than at Ashburton, so that, without paraquat spray, yield of Tama ryegrass was considerably lower. Paraquat spray had greater relative effect at the Oxford than at the Ashburton site. Paraquat treatments gave 300 to $700 \mathrm{~kg} / \mathrm{ha}$ higher yield from total grasses in cool season (March-August) at Oxford,. but had no effect at Ashburton. Applied nitrogen gave about 7 to $10 \mathrm{~kg}$ additional $\mathrm{DM}$ per $\mathrm{kg} \mathrm{N}$.

At Oxford, there was negliglible yield of perennial ryegrass where the pastures had been sprayed with paraquat. When Tama ryegrass died in fate spring, there was a marked slump in yield because only the clover base was left productive. The low yield from clover reflects, not only the effects of considerable competition from Tama ryegrass under infrequent grazing, but also dry 


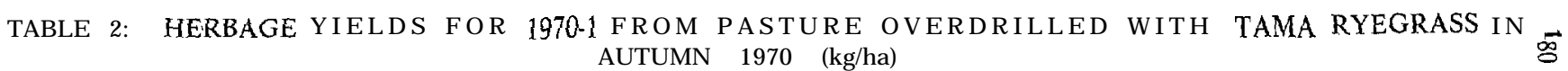

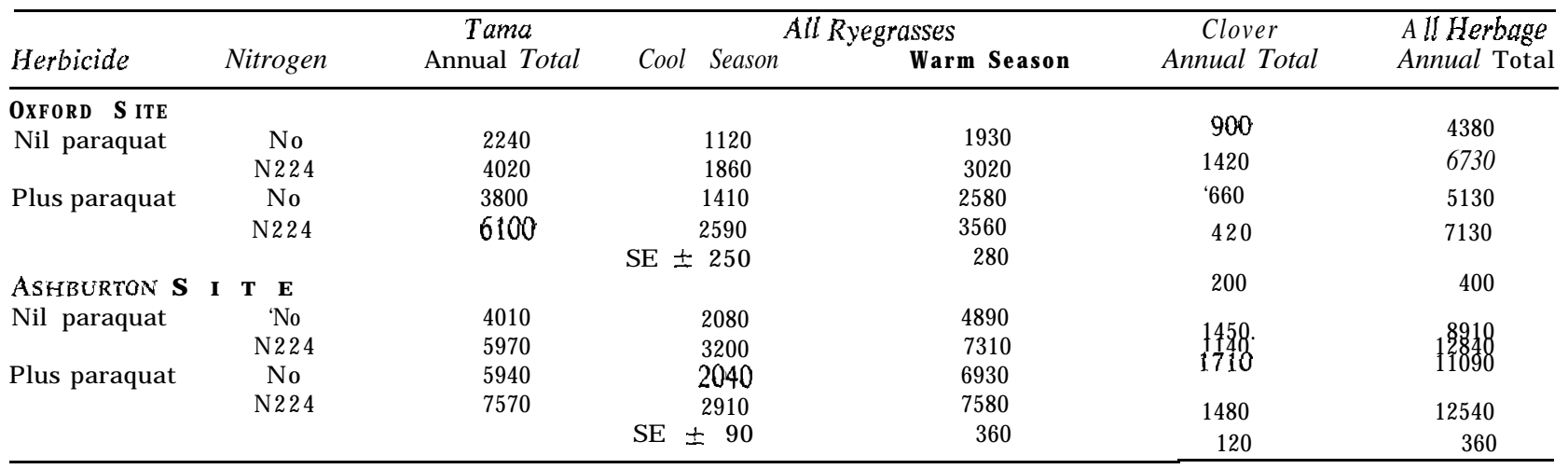

TABLE 3: HERBAGE YIELDS FOR 1971-2 FROM PASTURE OVERDRILLED WITH TAMA RYEGRASS IN (Second overdrilling of paraquat treatments from autumn 1970 only)

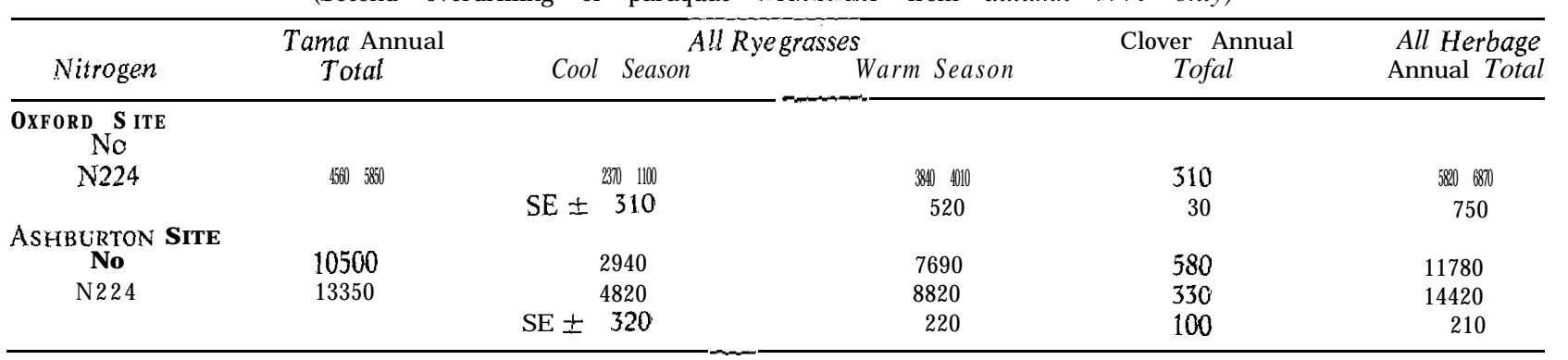

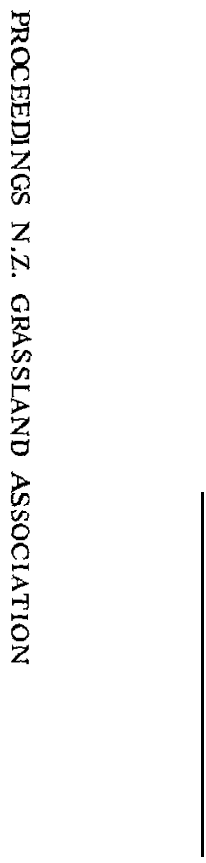


summer conditions adversely affecting clover growth. At Ashburton, yield of perennial ryegrass from the paraquat treatments was about $\mathbf{3 0 0 0} \mathrm{kg} / \mathrm{ha}$ and, if irrigation could have been applied in summer, reasonable pastures would have been maintained. YIELDS FOR 1971-2 From Pasture OVERDRILled with TAMA
RyEGRASS IN AUtUMN 1971 - TABLE 3

The subsequent overdrilling with Tama ryegrass gave similar yields at the Oxford site to those obtained in the previous year, but considerably higher Tama yields at the Ashburton site. Competition from Tama ryegrass reduced perennial ryegrass yield to a negligible amount. Nitrogen had a greater effect in increasing cool season yields than in the previous year $(11$ to $17 \mathrm{~kg}$ additional DM per $\mathrm{kg} \mathrm{N}$ ). At both sites there was a considerable slump in herbage production when Tama ryegrass died, because the clover had been considerably weakened.

Yields FOR 1971-2 From Pasture OVERDRILLED with ARIKI RyegrasS IN AUtum 1970 -TABLE 4

Ariki ryegrass could not be distinguished from Ruanui ryegrass. Data for the first year from overdrilling, in which Ariki ryegrass was establishing, are not presented.

For cool season there was nil or only a small increase in yield from paraquat treatments, contrasting with treatments where Tama ryegrass was overdrilled. Applied nitrogen increased grass yield in cool season by 8 to $9 \mathrm{~kg}$ additional $\mathrm{DM}$ per $\mathrm{kg} \mathrm{N}$ at Oxford and by 10 to $\mathbf{1 5} \mathbf{k g}$ at Ashburton. Clover yields were markedly higher than those from pasture overdrilled with Tama ryegrass. With the perennial ryegrasses there was not the same slump in pasture production in late spring as with Tama ryegrass.

Figure 1 shows how the distribution of herbage grown in cool season varied according to cultural practice at Ashburton in 1971-2. For pasture overdrilled with Ariki ryegrass there was no improvement in winter contribution to annual herbage yield (less than 10\%), but overdrilling with Tama ryegrass increased winter contribution to about $20 \%$.

The results from these experiments indicate that production in cool season from overdrilled species is in part dependent upon favourable moisture conditions for, their establishment and in part upon adequate nitrogen supply for their growth. Thus, at the irrigated Ashburton site, yields of overdrilled pasture without 
TABLE 4: HERBAGE YIELDS FOR 1971-2 FROM PASTURES OVERDRILLED WITH ARIKI RYEGRASS IN AUTUMN $1970(\mathrm{~kg} / \mathrm{ha})$

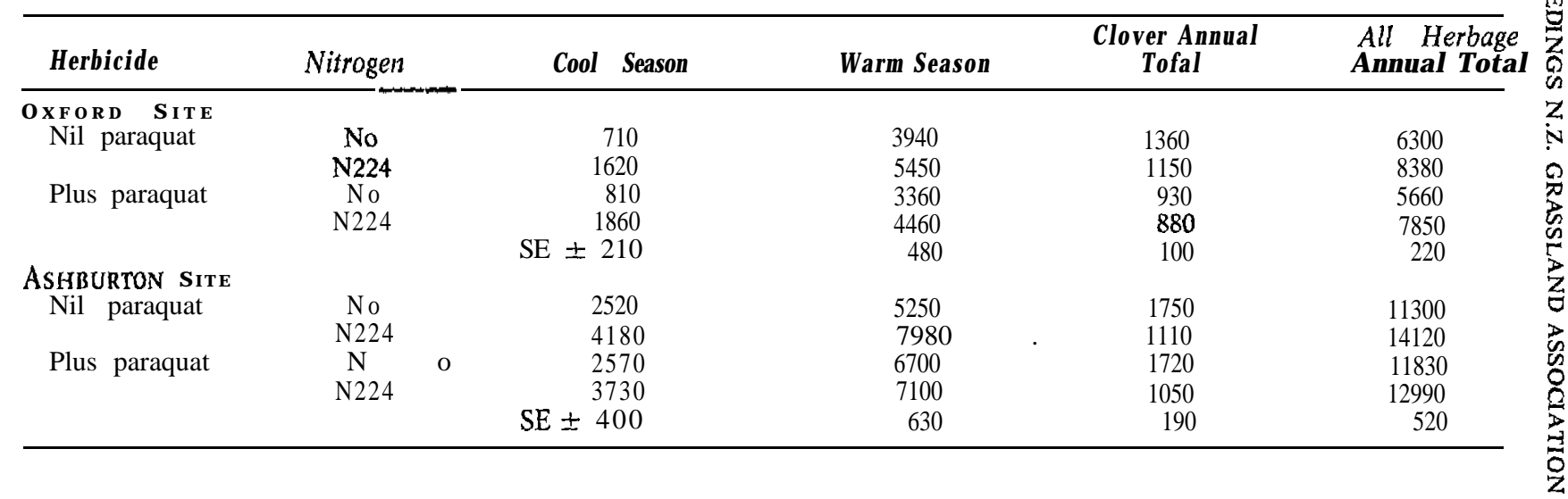


OVERDRILLED PASTURE IN CANTERBURY

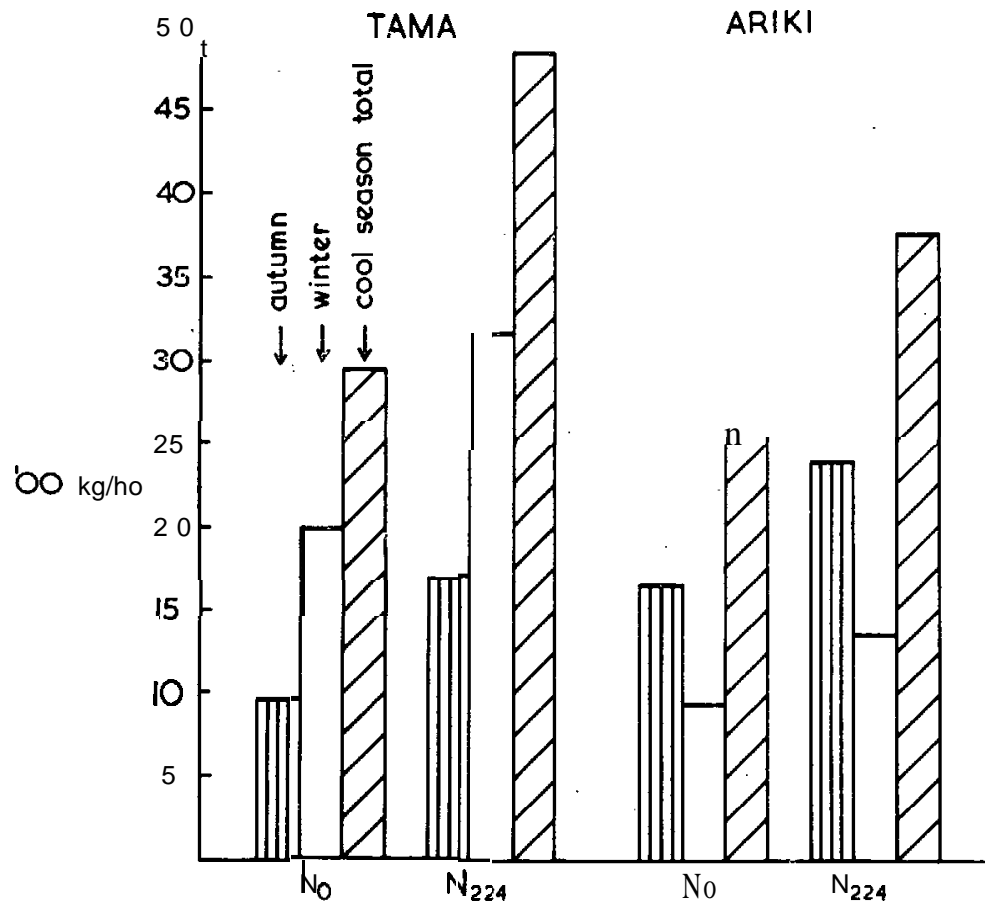

FIG, 1: Cool season disfribufion of herbage yield - Ashburton site, year $1971 \cdot z$.

nitrogen in cool season (2040 to $2940 \mathrm{~kg} / \mathrm{ha}$ ), compared with average values of $3000 \mathrm{~kg} / \mathrm{ha}$ obtained at Lincoln from Ruanui ryegrass pasture (O'Connor et al., 1968) and were generally higher than average values of 1510 to $2050 \mathrm{~kg} / \mathrm{ha}$ obtained at Winchmore from irrigated Ruanui ryegrass pasture (Rickard, 1972). Nitrogen increased yields by 45 to $65 \%$. At Oxford, yields of overdrilled pasture without nitrogen in cool season (810 to $1400 \mathrm{~kg} / \mathrm{ha}$ ) were lower than at Ashburton, but nitrogen gave substantially greater percentage increases in yield (84 to 130\%).

A current improvement practice for' pasture damaged by grass grub in Canterbury is to overdrill in autumn with both Tama and Ariki or Ruanui ryegrasses. Insecticide is also drilled with the seeds. The Tama ryegrass could then contribute to the immediate needs for cool season herbage production. Pasture production from the mixed overdrilling would not be expected to slump to the same extent in spring as shown when only Tama ryegrass is overdrilled. 


\section{ACKNOWLEDGEMENTS}

The experiments were carried out with the co-operation of C. and J. Austin, "Aroha Downs", Oxford, and J. S. McLauchlan and Sons, "Grassmere", Lismore.

\section{REFERENCES}

Kear, B. G.; Gibbs: H. G.; Miller, R. B., 1967: N.Z. Soil Bureau Bulletin $14.92 \mathrm{pp}$.

O’Connor, K. F.; Vartha, E. W.; Belcher, R. A.; Coulter, J. D., 1968: Proceedings of the N.Z. Grassland Association, 30: 50-63.

Rickard, D., 1972: N.Z. Ministry of Agriculture and Fisheries Winchmore Irrigation Research Station Technical Report 5. 26 pp. 